\title{
BUSINESS SCHOOL MAKEOVER; A INDUSTRY PERSPECTIVE
}

\author{
Ramesh Subramoniam and Avanti Sethi
}

\author{
Naveen Jindal School of Management, University of Texas, Dallas, USA
}

\begin{abstract}
Business schools across the United States and abroad are always on a catchup mode with the industry expectations. Why business schools are not front runners in training students for industry and consulting? Authors of this article discuss this topic by first setting the expectations from the industry and then how business schools can cope up with the evolving trends. Many authors ([1], [11], [13]) have identified the skill gaps in the industry and how business schools can work towards bridging the gap. There are research reports such as [13], that identified the misconception about the business schools expectations based on a survey of business school leaders globally (excluding China and USA). In the USA, even though business schools have strived hard to create an industry pro-environment in the class rooms, the gap continues to exist. The authors of this article address the industry needs first and explore potential solutions to address the skills gap.
\end{abstract}

\section{KEYWORDS}

Industry expectations, business education, innovation, experiential learning

\section{INTRODUCTION}

Financial times [1] quoted the following skills as critical for employers after doing a survey with employers based on a survey of 48 companies globally such as Brazil, China, US and Europe. These employers were leading businesses around the world, recognized as leading recruiters.

1. Ability to work with a wide variety of people

2. Time management and ability to prioritize

3. Understanding digital impact on businesses

4. $\quad$ Ability to build, sustain and expand network of people

5. Ability to solve complex problems

The five most important skills were not core MBA subjects, such as finance and marketing, but more loosely defined qualities, or so-called soft skills, such as the ability to work with a wide variety of people (cited by 76 per cent of employers) and the ability to prioritize (cited by 72 per cent). The survey also identified story telling skills and big data analysis skills as the most difficult skills to recruit. There are other publications that have reported similar findings such as the QS Employer survey report [15], where the employers reported teamwork, communication and problem-solving skills as the top skills that are required. In the Consulting field, Communication was identified as the most important gap. The students on the other hand [15], were under the impression that creativity, organization and problem solving as the key skills they need to get from the University. This gap in perception is based on the training they get from their respective universities. All of these reports are not downplaying the importance of technical skills, but emphasizing the importance of soft skills, which is not easy to teach in business schools. 
Business education is at the cusp of a major upheaval. New and emerging technologies such as artificial intelligence, smart robots, nanotechnology, the internet of things, increased global connectivity and computing power, biotechnology and genetic engineering, will redefine work and transform how businesses are staffed, operated, and managed. As robots and data analytics tools take over the ability to analyze and comprehend data and in some cases even be prescriptive, the new work force in the business world will need to use their time more smartly. Also, more time will be spent on how to make it work in a company business setting, which is driven by cultural, leadership, multi-disciplinary and interpersonal skills. What this means for future students is to learn how to drive change and have the ability to accept failure, ability to cope with change and continue to experiment with new ideas. The management and leadership model that preached domination will become extinct and a collaborative, experimental leadership model continues to become the norm. Also, students need to be more down to earth vs know it all so that they can connect with all levels of the organization, which is critical to drive change. The business school programs should be open to more courses outside of the business school so that more inter-disciplinary aspects are integrated in the curriculum that will drive the need to be more resilient towards failure and accept the "test and learn" approach for the prospective students.

\section{INDUSTRY EXPECTATIONS}

Business school students aspiring for potential industry jobs can be broadly split into two categories. 1. Traditional companies such as GM, GE etc. 2. New generation companies such as Amazon, Google, Apple etc. There are similarities and differences in the expectation of these two different types of companies in how they recruit students. Let us take a look at the traditional companies. These companies struggled through the financial crisis of 2008 and have emerged as more efficient with lean, nimble operations with a technology focus. Their goal is to continue to grow the business efficiently and staff resources to capitalize on emerging trends such as the digital technologies, internet of things, RFID etc. This expectation then translates into hiring new recruits who are innovative, be able to take the initiative to drive a concept to launch as new products, processes etc. Speed to market has become more critical as traditional companies collaborate with technology firms to provide products and services in the market place. For example, Delphi Corporation, a traditional mechanical, manufacturing automotive components supplier, a spin off from General Motors has focused more on becoming more of a connected product software company with the capabilities to manage data in the vehicle, transmission of data to the cloud and manage data in the cloud. More technology acquisitions and collaborative partnerships are happening as we speak in the automotive space. What this means is for future recruits to be more prepared for radical changes in the work place.

Companies such as Amazon, Google, Apple etc have set expectations in the market place with strong new hire capabilities expected in data driven decision making, innovation, quantitative analysis and modeling skills, collaboration, communication and writing skills. Amazon advocates using written reports than power points for company meetings. This translates into the employees who can tell the story in a succinct way in those reports. Story telling is the capability to think holistically about the situation or a problem and articulate succinctly the way to approach and also to convince the management or the team to get buy in with regard to your approach. 
International Journal on Integrating Technology in Education (IJITE) Vol.8, No.4, December 2019

\section{CONSUlting Firm EXPECTATIONS}

Consulting firms have 6 major domains such as Strategy, Management, Operations, Finance, HR and Technology and 200+ sub-domains or specialized forms. These practice areas differ in terms of employee expectations such as the Private Equity and Corporate Performance Improvement practices. Private equity (PE) firms continue to look for $M \& A$ deals and look for closing them quickly. This type of business activity requires employees who are highly skilled and identify opportunities, perform quick assessments and capable of presenting them to PE partners in a matter of a week or two. Speed is the essence for PE jobs. Corporate environments provide little more time and can help fresh recruits from school learn and grow before they can develop the speed. Story telling is the ability to articulate a potential solution and rationalize it to a client. This ability combined with data driven analysis is what is required in a consulting profession. The continuous changes in data and the ability to make quick changes should not be discounted. The need for experience in analyzing large amounts of data along with the ability to visualize and communicate them to senior executives is what is expected from employeestoday.

As the employee gains experience, consulting firms expect them to be rain makers, in other words ability to develop new business or sales to make it to partner level. The key skill required for this effort is the ability to network and sell. Not everybody can be a partner. Many consulting firms such as Mckinsey and BCG offer alternate "Expert" career tracks, where you can continue to build your technical skills and excel in delivering projects than develop sales.

\section{BUSINESS SCHOOL APPROACH}

Avanti et al. [14] in their article talked about the formula-based approaches followed by business text books and how it can detrimental for students trying to understand the concepts. Business schools on the other hand, has added capstone projects, industry certifications, business case competitions etc. to their portfolio to get closer to the industry needs. Based on recent research, industry has pointed out that business school graduates lack skills in the following areas such as critical thinking, communication, business writing etc.

Business schools for a long time have relied on case studies as a method to teach students. The case studies are written by business school faculty and students discuss and come up with solutions based on a complete set of well-defined data in most cases. Most case studies have well defined problem statements, which is not the case for real life situations. The case studies also can miss the subtle soft side of the business such as the impact to the workers and even the community at large. The case study learning vs experiential learning is like driving a car in a video game to driving a real car. Both are effective, but only one prepares you for real life. Most situations in real life are based on a compromise and can be learned only by experience.

\section{Conclusions}

Business schools are moving towards experiential teaching, similar to what some of the consulting firms have done internally for training fresh recruits. This involves creating a real life business situation as close to realty as possible. Teaching soft skills is difficult, but practicing them can be achieved through live situations and can be monitored and developed by the faculty. Consulting companies demand not only the ability to identify data needs and analyze data, but also the ability to present the data in a convincing manner to get the buy in from senior leadership. This is the essence of business school teaching for the future. The ability to innovate and simulate real life situations in class rooms. Even though the case studies business schools use today were developed to achieve that goal, they fail to replicate the soft skills so much 
International Journal on Integrating Technology in Education (IJITE) Vol.8, No.4, December 2019

required in the real world today. This can be achieved only through experiential learning. Experiential learning relies on experience, rather than on text books and case studies to learn.

Also business schools should look beyond their four walls into other disciplines such as dental, medicine and law to understand how they train practitioners and their capability to combine high quality research with practical teaching. This is the need of the hour and the technology changes demand that the business education ramp up to meet the needs of the corporate and consulting needs or give way to corporate universities. The business needs will be met one way or the other in the coming years.

At Essec for example [2], business analytics classes, which include consulting skills, integrate projects based on real-life sets of data. Partner companies provide data and business problems to solve: the students are required to analyze the data and come up with a solution. They deliver a presentation to the top management and are assessed on both the methodological aspects (hard skills) and the presentation structure and quality (soft skills).

At the University of Texas, Dallas, Jindal School of Management's entrepreneurial experience business course takes students from various disciplines such as business, engineering etc. through an entrepreneurial journey starting with selection of ideas, development of the business case and finally create a compelling case to be presented to senior management. The most recent course focused on developing Internet of Things supply chain solutions for a major telecom service provider. The students are split into teams and a mentor is assigned to every team from the partner company. The partner company take the best ideas to implementation.

Simulation games [16] in a class room environment can provide another way to create an experiential learning environment. The instructor can set up the game with specific learning objectives in mind and let the teams be creative in coming up with solutions under time pressure. There is no definition of a problem statement as you see with case studies. The students have to figure out the problem and connect that to potential solutions, split responsibilities and solve the problem at hand with the limited time available.

Student internships [17] and capstone project courses with companies provides the experiential learning and improves employability for students. Many companies convert their interns to full time positions based on their interaction with the interns. This is a mutual benefit for the student and the company to see if there is a fit and helps career satisfaction and potential longer-term employment.

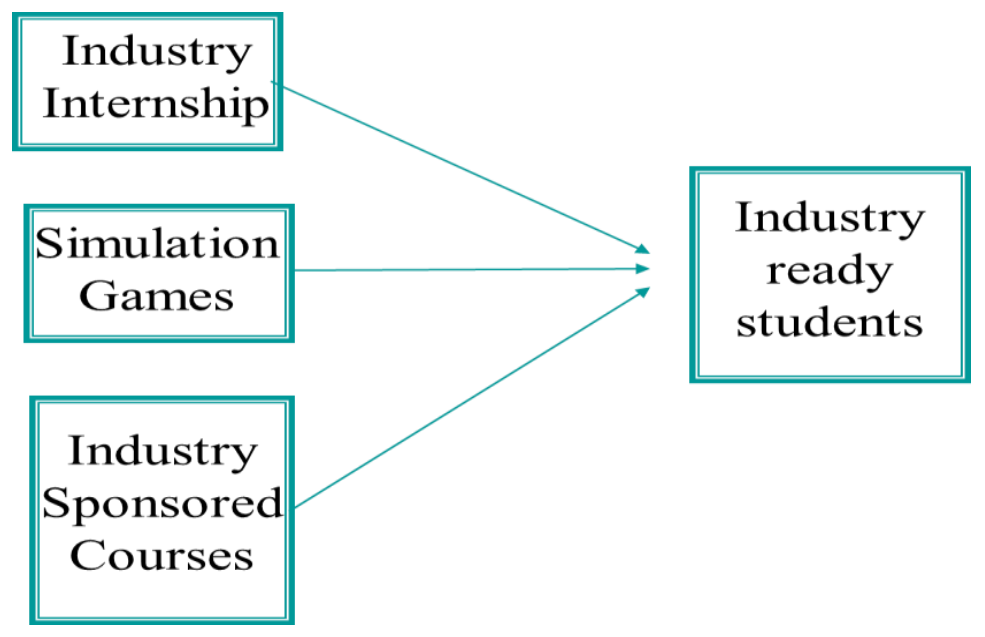


International Journal on Integrating Technology in Education (IJITE) Vol.8, No.4, December 2019

The university partnership efforts combined with simulation games and industry internships as mentioned above with industries can develop the future business talent to take on the challenges as companies embrace the digital age. There is a lot of dramatic changes happening in the digital partnership ecosystem and without a real time industry partnership with students, the future workforce will be in the dark when they enter the workforce.

The current research is based on the industry and academic experience of the authors and prior research work. The limitation of this study is the focus on the US and limited exposure on other countries. A comparative study that focuses on business education in other countries such as India and China will provide a good benchmark and best practices to compare with the management education in the USA.

\section{REFERENCES}

[1] What employers want from MBA graduates and what they don't, Financial Times, August 2017.

[2] What MBA students want and what they need, Financial Times, Feb 2018.

[3] http://www.f1gmat.com/experiential-learning-vs-case-based-study-method

[4] 21st Century Skills, Education \& Competitiveness, A Resource and Policy Guide, "Partnership for 21st Century Skills".

[5] Autor, D., Levy, F. \&Murnane, R. (2003). "The Skill Content of Recent Technological Change: An Empirical Exploration. Quarterly Journal of Economics, 118(4), 1279-1333.

[6] Barr, R.B., \&Tagg, J. (1995). From Teaching to Learning - Anew Paradigm For Undergraduates Education. Change, Nov/Dec, 13-25.

[7] Blishen, E. (1969) The School that I'd Like. Harmondsworth:Penguin.

[8] Ewing Marion Kauffman Foundation. (July 2007). On the Road to an Entrepreneurial Economy: A Research and Policy Guide. Kansas City, MO: Author.

[9] FICCI (2010), "What corporates expects from you: Experts' guide to student managers", Macmillan publishers.

[10] Freiberg, J 1998, 'Hire for attitude, train for skill', Executive Excellence, HBR, vol. 15,no. 6, June, p. 7.

[11] GabrilHawawini (2005), "The Future of Business Schools", Journal of Management Development, Vol 24, No 9.Pg 770-783.

[12] Jaysankaran. N (2010), B school teachers: Teaching with passion in 'What corporates expects from you' edited by FICCI, Macmillan Publishers.

[13] John Rayment and Dr Jonathan Smith (2010), The Current And Future Role Of Business Schools, Research Report, Anglia Ruskin University, Cambridge and Chelmsford, England.

[14] Sethi, Avanti and Subramoniam, R., “ Use of Technology in Education, but at what Cost?", International Journal of Technology in Education, 2019.

[15] Global Skills gap in the 21st century, QS Report, 2018. 
International Journal on Integrating Technology in Education (IJITE) Vol.8, No.4, December 2019

[16] S. Krishnan, "Redefining Education to Employment Journey: Changes in Commerce and Management Education," Parikalpana: K I I T Journal of Management, vol. 11, (1), pp. 88-98, 2015. Available: https://search.proquest.com/docview/1692919060?accountid=136238.

[17] Chi, C. G. and Gursoy, D. (2009). How to help your graduates secure better jobs? An industry perspective. International Journal of Contemporary Hospitality Management, 21, (3), 308-322.

\section{AUTHORS}

Dr. Ramesh Subramoniam, a faculty member at the Jindal School of Management at UT Dallas, received his PhD from Erasmus University, Rotterdam, NL and joined UT Dallas with 27 years experience in industry and consulting.

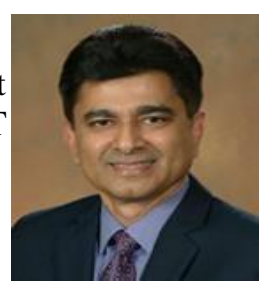

Dr. Avanti Sethi, a faculty member at Jindal School of Management at UT Dallas, received his MS and PhD in Operations Research from Carnegie-Mellon University in Pittsburgh, USA.

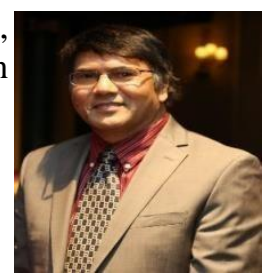

